\title{
WILEY

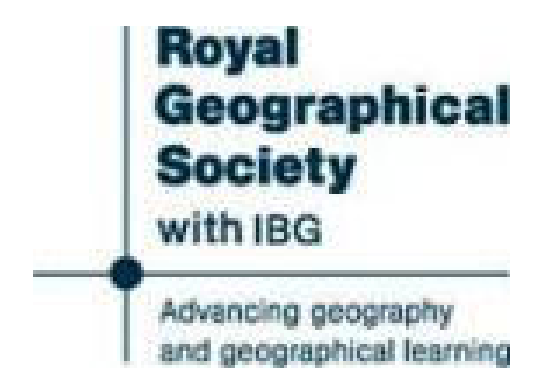

On the Geographical Results of the Mission to Kashgar, under Sir T. Douglas Forsyth, in 1873-4

Author(s): H. Trotter

Source: Proceedings of the Royal Geographical Society of London, Vol. 22, No. 4 (1877 - 1878), pp. 287-291

Published by: Wiley on behalf of The Royal Geographical Society (with the Institute of British

Geographers)

Stable URL: http://www.jstor.org/stable/1799740

Accessed: 17/06/2014 17:03

Your use of the JSTOR archive indicates your acceptance of the Terms \& Conditions of Use, available at

http://www.jstor.org/page/info/about/policies/terms.jsp

JSTOR is a not-for-profit service that helps scholars, researchers, and students discover, use, and build upon a wide range of content in a trusted digital archive. We use information technology and tools to increase productivity and facilitate new forms of scholarship. For more information about JSTOR, please contact support@ jstor.org. 
New Mexico (T. W. Goad). Diocesan Map of the Church of England in Newfoundland, by the Rev. J. J. Curling (the Author). The Victoria Nyanża Mission (R. N. Cust, Esq.). Plan of the Southern portion of the Province of South Australia, divided into Counties and Hundreds, 18 sheets (The Agent-General for South Australia). Admiralty Charts, 13 sheets (The Hydrographer). United States Charts, 1 sheet (Commodore Wyman, U.s.x., United States Hydrographer).

Before proceeding to the business of the evening, the President alluded to the melancholy intelligence, which had arrived since the last Meeting, of the death of Mr. T. T. Cooper, whose name was familiar to the members of the Society. Mr. Cooper had long been comnected with efforts for the exploration of Western China, and the routes across the frontier into India. The circumstances of his death were rather obscure. He appeared to have been killed in some affray with his own guard, and a Sepoy seemed to have fallen a victim with him. Although not a scientific geographer, he was a very ardent explorer, his object being to open up new routes for commerce through regions which had never before been penetrated by European travellers. Men of this class were not so frequently met with that they could be permitted to pass away without a few kind words to their memory.

The Paper to be read was by Captain H. Trotter, on the Geographical results of Sir Douglas Forsyth's important expedition to Kashgar. Under the orders of Sir Douglas Forsyth, Captain Trotter penetrated to those elevated regions north-west of Kashgar, of which previously very little was known, and being a man of high scientific attainments, he was able to make observations of great geographical value. One part of his Paper would describe the lofty plateau and passes of the Pamir, poetically termed by the Persians, with a touch of Oriental imagery, the "Roof of the World." When a man reached to 20,000 feet above the level of the sea, a height attained in some portions of the journey, he must get what was popularly called a bird's-eye view in the fullest sense of the word.

Captain H. Trotter, R.E., Deputy Superintendent of the Great Trigonometrical Survey, then read his Paper:-

\section{On the Geographical Results of the Mission to Kashgar, under Sir T. Douglas Forsyth, in 187:-4.}

The Mission left India in the summer of 1873, and was absent rather more than a year. The author stated that a considerable amount of literature already existed on the subject of the Expedition; for, besides very voluminous reports to Government from the seven European officers, of whom the Mission was composed, two books on the same subject had been published in England, viz., the 'Roof of the World,' by Colonel Gordon, and 'Kashmir and Kashgar,' by Dr. H. W. Bellew. The present Paper was taken in great part from Captain Trotter's own section of the official Reports, of which not many copies were printed, and very few made available to the general public. 


\author{
The Paper will be printed entire, with a Map, in the 'Journal,' \\ vol. xlviii.
}

The President expressed his great regret at the absence on that occasion of Sir Henry Kawlinson and Colonel Yule, our two greatest authorities on Central Asia. Sir Henry, he was sorry to say, was kept away by indisposition, otherwise he was sure he would not have failed to be present when a subject was discussed in which he tock so deep an interest. The Meeting had, however, the advantage of the presence of Sir Douglas Forsyth, who undoubtedly was a great authority on this subject, as he was the head of the Mission to which Captain Trotter was attached. The region which had been described was one of the most interesting in Central Asia. It was the great source from which so many successive waves of population had flowed towards the West. Why such should have been the case was one of those problems which had never been satisfactorily solved, but all tradition seemed to point to the great central plateau of Asia as the home from which the nations of Western Europe originally came. That fact alone gave considerable interest to the region. Sir Brooke Robertson, who had long been in China, was also present, and as the attention of our diplomatic staff in that country had naturally been directed to the operations of the Chinese Government, which had recently, by one of the most extraordinary marches and campaigns in its history, recovered possession of Eastern Turkistan, lost to them by revolt some twelve years ago. This afforded a remarkable instance of the tenacity and perseverance with which that great people held on to any object that they had once attempted. A great many years ago, when the question of an alliance with Kashgar was under consideration, he (Sir Rutherford) expressed his conviction that the Chinese Government would never fail, sooner or later, to make such vigorous efforts as would probably recover the lost province. It had simply been a penal settlement, but their national pride and doggedness of disposition would lead them to recover it. Yakoob Beg had now passed away, and nearly the whole Mussulman population had been exterminated for the second time, which was the only way in which these Eastern races understood the conquest of a country. 'T'hey had done the same in Yunnan and the South-Western Provinces. A great deal had been heard about Bulgarian atrocities, but really those Eastern races had no other idea of making war but destroying their enemies. They had done so for two thousand years, and, to all appearances, would continue to do so. The campaign, however, was a very strange one. Finding that their commissariat was insufficient, and that there was no food for them, the army from China turned their swords into ploughshares for a season and grew a crop of rice. Then they moved on again. This was a new mode of warfare. It required that time should be no object, and that there should be men in abundance. Although he did not suppose that the days of Yengis Khan or Timour the Tartar would return, there was no doubt that the Chinese Government could send two or three million men across the whole breadth of the continent, if they chose to take it into their heads to do so. These, however, were rather speculative matters. What the Meeting chiefly wished to know was whether there was any prospect of establishing peaceable commercial relations across these great and formidable passes; and no doubt Sir Douglas Forsyth would be able to say what hope there was of ever realising Mr. Shaw's dream of a large and beneficial intercourse between India and Eastern Turkestan.

Sir Douglas Fonsytr said he wished to add his mite of applause to that which had been given to his frieud Captain Trotter, and to congratulate him on being the Gold Medallist for the year. He knew how much he desired this distinction, and he could testify how thoroughly it had been deserved. 
The Society had honoured itself by honouring Captain Trotter and enrolling him in their list of medallists. When Lord Northbrook determined on sending the Mission to Kashgar, he very wisely decided not to leave the scientific results to haphazard, and therefore appointed two professional, scientific men to take advantage of the opportunity to collect all the information they could regarding the interesting region to be passed through. One of these officers was Captain Trotter. He (Sir D. Forsyth) had witnessed the patience, endurance, and marvellous care with which he had pursued his investigations, and therefore he most heartily joined in congratulating him on having achieved such glorious results. A few days ago a Paper was read by Dr. Marcet at the Royal Society on the difficulty of respiration at an elevation of 13,000 feet. Captain 'Trotter had been at an elevation of 19,000 feet, not only for one, but for several days, and had worked his instruments in a most laborious way. The best way he knew to convey an idea of a person's feelings at such a height was to ask ladies who were not good sailor's to remember their sensations when crossing the Channel; yet, in spite of these difficulties, Captain Trotter made most accurate observations, and recorded them in the most accurate manner. It might seem an extraordinary thing to people at home to learn that the cold was so intense in those parts; but from September till April the thermometer at night never rose above freezing-point, and for weeks together it was below zero. For the greater part of that time the Mission lived in tents, not in comfortable houses. $\mathrm{He}$ recollected one morning, the cold being very severe, calling out to Captain Trotter, who was in the next tent, to know what the thermometer had registered during the night. The answer that came back was " $25^{\circ}$ below zero." On one occasion Colonel Gordon, when out shooting, omitted to keep his gloves on, and on touching his rifle-harrel his hand became one mass of blisters. Captain Trotter, however, worked his instruments night and day with the utmost care, notwithstanding all the difficulties he had to contend with. On Dr. Stoliczska the cold told with fatal effect. He was a most remarkable man. He was originally appointed to the Expedition on account of his attainments as a geologist, botanist, and naturalist, but he was well versed in the kindred science of geography. On every subject he seemed to be brimful of information, while he had that charm of modesty and engaging manner in imparting his knowledge which made it quite a treat to be in his society. He could not, however, stand the cold on the heights. He struggled through to the Sir-i-Kol and over the Pamir, and on his return reached almost the last pass, where he succumbed, and he was buried at Leh. The Pamir was the great line of the trade-routes between China and Persia in the very earliest days of history. The exact route which was followed was still doubtful, but it must either have gone from Yarkand to the valley of the Oxus, or from Kashgar right across Khokan to Indajan. Sir Henry Rawlinson would not hear of this latter route being the true one, but if he had been on the spot he would have allowed that there was a great deal to be said in its favour. The President had spoken of the Pamir as being the "Roof of the World," as though it was the highest part. That, no doubt, was the popular idea, but the Karakorum Mountains were much higher; and while the passes over the Pamir were only from 13,000 to 14,000 feet, those over the Karakorum were from 19,000 to 20,000 feet. For centuries this region was part of the empire ruled over by a long line of Scythian kings. Herodotus spoke of the Messagetæ, the Issedones, the Sacæ, and other tribes as inhabiting the country, and the hordes of Vandals, Goths, and Huns had their origin there. Dr. Bellew, who was the medical officer to the expedition, was a wonderful linguist, who was perpetually studying the languages and examining all the manuscripts he could find in those parts. Undoubtedly the Hungarians were of opinion that they came from there. Vambéry once told him that the object of his journey to 
Bokhara was to ascertain the origin of his own race, though probably there was a political object as well. One day, when he (Sir D. Forsyth) was at Yangi-Hissar, while Captain Trotter and his party were crossing the Pamir, he heard that a Magyar Pole had crossed from the Russian frontier to Kashgar, and was asking eagerly for the English Mission. When the meeting took place, he said, "Oh, I have come to find the cradle of my race : I am told it is somewhere in these parts ;" but wherever the English party went, he went with them. It turned out that he had been sent over to find out what the Mission were doing, and on pretence of looking for the cradle of his race, he settled himself in the English camp. Ultimately, as they did not want him with them, they gave him a horse, with provisions, and sent him to Kashmir, with a letter to the Maharajah, requesting him to send out people to receive him. He was well treated, and ought to have been exceedingly grateful, but, instead of that, he abused him (Sir D. Forsyth) in the most frightful manner. To have a discussion on Central Asia without Colonel Yule was like the play of 'Hamlet' with Hamlet left out; but what he would have said if he had been present might be gathered from his preface to Prejevalsky's work, where, alluding to subsequent travellers in that part of the world, he wrote that they merely followed in Marco Polo's footsteps, and their labours fell very far short of what Marco Polo himself had done. No doubt that was true, but in Marco Polo's days no European powers had appeared in Asia to disturb the equanimity of the people. Since then, however, they had learned to be rather afraid of Europeans. Until within the last fourteen or fifteen years the Chinese, who were masters of Yarkand and Kashgar, would not let any foreigner, European or Hindoo, enter the country, which was therefore a sealed book, until the wave of Mohammedan rebellion, which began in the Western portion of China proper, spread towards Yarkand and Kashgar ; and then Yakoob Beg founded his kingdom. He was a very remarkable man, sui generis. It was quite true that he established his power by a great deal of severity, but the result was that the most perfect peace reigned throughout the whole of his kingdom to such an extent, that bales of goods which unfortunate travellers had been compelled, by the loss of their ponies or camels, to leave on the road, remained untouched, as nobody would dare to meddle with them. The inhabitants too were all Mobammedans, but of a different type from what had lately been supposed to characterise Mohammedans. They were a simple, industrious, hospitable, friendly people. Wherever the English party went they were received with the utmost kindness. 'This must be put to the good account of the late Yakoob Beg, who, however, was rather afraid of giving offence to the Russians, and therefore would not allow the Mission to carry out all the explorations that they had intended. 'The intention had been to go from Kashgar to Uksu, then to Lake Lob, and crossing to Tibet. Everything was arranged, but at the last moment Yakoob Beg sent a message to say that for certain reasons it would be better that the Expedition should be abandoned. The consequence was that the honour of discovering Lake Lob and the adjacent country fell to Colonel Prejevalsky, whom, when the proper time came, the Royal Geographical Society would no doubt welcome with due honour as one who had made a grand discovery. Yakoob Beg was assassinated about the middle of last year, and, in the anarchy which followed, the Chinese general was able to push his troops forward, and on the 6th or 7 th of December to enter Kashgar. After slaughtering an immense number of people, he had now re-established the Chinese rule. He did not, however, think that all the male inhabitants had been killed. He hoped the Chinese would not fall back upon their old system of exclusion. By the Che-foo convention they had agreed to open many parts of the Empire, and perhaps they might be induced to allow the English to establish a Consulate at Yarkand. Setting aside these political considerations, he thought that a 
country which, within the last eight ycars had produced three or four Gold Medallists, must be one in which the Royal Geographical Society would feel considerable interest. He trusted that Sir Henry Rawlinson and the other members of the Indian Council who were connected with the Society would do their utmost to keep that region open for the benefit of future explorers.

The President said the Council of the Society were perfectly unanimous in voting the Patron's Medal of the year to Captain Trotter, as one who had richly earned any distinction which they had it in their power to confer. It was quite clear that, at seasons of such intense cold, when to touch metal was to blister the fingers, to use his instruments with such effect as Captain Trotter had done must indicate the possession of some very rare qualities, not only of perseverance but of hardihood. If the region which had been described was really the cradle of the race, it must be a very large cradle, for it had sent forth a very numerous progeny. He could not agree with Sir Douglas Forsyth in his estimate of the slaughter which had taken place by the Chinese in the territory formerly governed by Yakoob. Beg. He believed that they had, as nearly as might be, exterminated all the male inhabitants. They did the same thing in Yunnan, and when he was in Canton 70,000 men were decapitated in one year in the execution grounds. Sir Douglas Forsyth had not touched upon the physical difficulties which the passes presented to commerce, but he was afraid that there was not much chance of ever establishing a large and lucrative trade by caravans between India and Kashgar. Still it was desirable, if possible, to have a friendly and continuous communication between the two countries, and no doubt this would have been secured by such diplomatists as Sir Douglas Forsyth, and such accomplished scientific explorers as Captain Trotter, but for the assassination of Yakoob Beg and the destruction of the people over whom he had ruled. The Council had for some time been desirous that Captain Trotter's Paper should be read to the Society, but, owing to his absence from England, it had been delayed till this evening. 